\title{
Development of Ispring 8 Learning Media with Power Point Assistance to Improve Listening Skills for Fifth Grade Elementary School Students
}

\author{
Sriyono $^{1 *}$, Setya Yuwana Sudikan ${ }^{2}$, Hendratno ${ }^{3}$ \\ Primary Education, Postgraduate, Universitas Negeri Surabaya
}

\begin{abstract}
This study aims to describe the development process and quality of media development which includes the validity, practicality, and effectiveness of the media in improving the listening skills of fifth grade elementary school students. This research is a type of research and development with 4-D model. Product trials are carried outat at elementary school Genilangit 02. The results of the research on the media development process in the define stage, design, develop, and disseminate obtained from the results of interviews with homeroom teachers of fifth grade showed the relevance of the media to student characteristics and the results of validation by experts showed a score of 3.90. The results of the research on media quality showed the validity of the media with a mean of 3.66, material 3.71, and language 3.75. The practicality of the media shows the results of 3.89 teacher responses and 4.0 on average student responses. The effectiveness of the media shows a score of $\mathbf{3 . 8 3}$ teacher responses and 4.0 on average student responses,an increase in learning outcomes 2.37 (23.7\%) with an increase in mastery of $30 \%$. The average score of student learning activities is $100 \%$. Power pointassisted iSpring 8 media development is very feasible with the Four-D development model so that it can be tested. The quality of the media shows high validity of the results of the validation test, high practicality of the results of the respondents' questionnaires, and high effectiveness in improving the listening skills of fifth grade students from questionnaires and student test results. From the research results, it can be concluded that the media development process has been carried out properly, the quality of the media shows high validity, practicality, and effectiveness in developing listening skills for fifth grade elementary school students.
\end{abstract}

Keywords:- Learning Media, Ispring 8 Assisted With Power Point, Listening Skills.

\section{INTRODUCTION}

The development of digital media in the global era cannot be stopped. This condition is a challenge for the world of basic education to answer the challenges of technological developments that are inherent in students' daily lives. Teachers can take advantage of online media such as websites to find learning tools or alternative digital media that are offline based, such as video players, CDs, power points, and so on to convey material. Seeing the ease of use of power point media and its suitability in supporting the iSpring 8 media, both can be developed into an attractive and attractive learning medium in supporting student learning activities.

Learning at the elementary level contains a variety of materials that students must master, including Indonesian language material which includes listening, speaking, reading, and writing skills. Listening skills generally receive less attention than other skills so that efforts are needed to provide various elements of learning that can measure students' listening skills. The increasing demands for the world of basic education to present learning that can accommodate technological developments and communication that develop in the student environment. As well as the neglect of elementary students' listening skills in Indonesian language material. Making iSpring 8 learning media with the help of power point displays is effective in measuring the improvement of listening skills for fifth grade elementary school students, especially in Indonesian language material and responding to technological challenges in the world of basic education. ISpring 8 media development assisted with power point display which will be used to improve the listening skills of fifth grade elementary school students using the Four-D model development method. Similar research has also been conducted by Himmamah and Martini regarding the development of interactive multimedia using the iSpring suite 8 to improve student learning outcomes in additive sub-materials. The use of power point-assisted iSpring 8 media in Indonesian language learning to improve elementary school listening skills has never been done in previous studies. Therefore, further research is needed. The research objective is to describe the development process and to describe the quality of media development which includes the validity, practicality and effectiveness of the media.

\section{THEORETICAL FRAMEWORK}

Media can be interpreted as a container for an object. According to Abidin (2015: 256) learning media are various tools that are used to improve student learning outcomes regarding the material being studied. According to Syukron (2008: 117) learning media is a series of tools that are used to facilitate the teaching and learning process, with the aim of streamlining the interaction between teachers and students in the learning process. According to Munadi (2012: 36) the function of learning media can be analyzed for its function in its use, including functions as a 
learning resource, semantic functions, and conversion functions. According to Kemp, et al (1985: 147) classifies learning media into six types, namely, print media, audio recordings, series of slides and film strips, multimedia presentations, video recordings, films, and computer assisted media.

Nurjaman (2014) give an opinion media iSpring 8 is a Microsoft support software that supports development formats, such as video recorders, voice recorders, quizzes, and storage formats so that the contents of power points cannot be manipulated by users with the public menu. According to Ani, et al (2019) iSpring 8 is software that provides supporting applications in facilitating the process of delivering learning by teachers. According to Wijayanto (2017) iSpring Suite is a computer assisted media that can help teachers present learning material and facilitate the application of various learning methods so that students will more easily understand the material. According to Nurwijayanti, Budiono, and Laili (2019) iSpring8 is a learning medium that can improve the quality of teaching and learning with the ability to convert power point files to flash so that media users cannot change the content and appearance of the media.. According to Arsyad (2014: 65), power point media was first developed by Bob Gaskins and Dennis Austin, in the form of software processing the presentation of text objects, graphics, video, sound, and other objects presented in the form of slides. According to Munadi (2013: 150) power point is software developed by Microsofr Inc which is assisted by a slide computer.

According to Oya and Budiningsih (2014) listening activity functions to train students to construct their knowledge from various things that are listened to. According to Djuanda (2008) listening is a basic skill for learning other skills. According to Tarigan, et al. (2006: 2.7) listening is an activity of listening, identifying, interpreting, assessing, and responding to language sounds that are emphasized by facial features, gestures, speaking songs and voice pressure.

\section{RESEARCH METHOD}

This research is a type of research and development. The research design used a 4-D model. The 4-D (Four D) development model is a learning device development model. This model was developed by Thiagarajan. The 4-D development model consists of four main stages, namely: Define, Design, Develop and Disseminate. The product developed is then tested for its feasibility with validity testing and product testing to determine the increase in listening skills of fifth grade elementary school students advertising text material in fifth grade. The data collected is related data (a) the iSpring 8 media development process assisted by power points, (b) the quality of the media developed to suit core competencies, basic competencies, and material coverage and adapted to learning needs fifth grade elementary school student. The quality of the media developed can be seen from the aspects of its validity, practicality, and effectiveness. The data analysis technique in this study used qualitative analysis techniques and quantitative analysis techniques.

\section{RESULTS}

\section{> Media Development Process}

The data analysis of the concept of learning media iSpring 8 assisted with power point is based on core competencies and basic competencies listed in the teacher's book and student's book refers to theme 9 sub-theme 2, learning 2. Task analysis of iSpring media assisted with power point, including understanding, structure, linguistic characteristics, types and examples of print and electronic media advertising text, completing assignments, and completing evaluation questions. The formulation of learning objectives is taken from the analysis of assignments that are adjusted to core competencies, basic competencies and the content of learning materials. types and examples of advertising text in print and electronic media, completing assignments, and completing evaluation questions. The formulation of learning objectives is taken from the analysis of assignments that are adjusted to core competencies, basic competencies and the content of learning materials. types and examples of advertising text in print and electronic media, completing assignments, and completing evaluation questions. The formulation of learning objectives is taken from the analysis of assignments that are adjusted to core competencies, basic competencies and the content of learning materials.

Results Description Planning Stage (Design) The preparation of the test is based on concept analysis and task analysis, the question grid is based on indicators of achievement of learning outcomes that have been formulated, namely C1-C5 questions. Media selection is based on task analysis and concept analysis as well as the availability of facilities and infrastructure in the school where the trials are computers, LCDs and atamedia projectors that can be transmitted to students via bweb / school blogs, social media networks, and Siakad or Sepakad. Format selection is tailored to the needs of students and the characteristics of the material in the form of a watch which is assisted by concrete illustrations of theme 9 , sub-theme 2 contains advertising text material for basic competencies in Indonesian,

The description of the results of the development (developed) carried out the validation test on the first draft test required adjustments to the media development process, the second draft test for the media development process in the definition stage showed a score of 3.80, the planning stage showed a score of 4.0 and the development stage showed a score of 4.0. The results of the validation show that the media development process shows very good criteria and no revision is needed to the development process that has been carried out with an overall score of 3.90 . 
Limited Trial was carried out based on initial data obtained from interviews with homeroom teachers of fifth grade at elementary school Genilangit 02 with eight students as subjects. The description of the results of the dissemination of iSpring 8 media assisted by power points at the diffusion stage, registering the results of this media development to a seminar or workshop on learning media for elementary schools. In the adoption stage, applicationbased media is disseminated through online and offline transmissions. Online dissemination is done through blog sites and YouTube channels

\section{$>$ Description and Data Analysis of the Validity of Learning Media}

The media validation test was carried out on two media experts, testing draft I by the media validator had to go through a series of adjustments around the structure and appearance based on the advice of the experts, in testing draft II the media had expert approval and was ready to be tested showing the average score of the two experts 3,62 for media presentation, 3.75 for images presented by media, 3.66 for video presented by media, 3.66 for voice presented by media, and 3.75 for writing presented by media with average validation score of both validators for medium is 3.66 .

Material validation was carried out three times because in testing draft I the media had to go through a series of adjustments around the learning objectives, in draft II the media required a systematic adjustment of the material based on expert advice, in testing draft III the media had received expert approval and was ready to be tested in the field with test results validation of the material with an average score of 3.71 then a media trial was carried out after checking and recommendations for media trials by material experts.

Language validation was carried out twice because in testing draft I the media had to go through a series of adjustments around the effectiveness of sentences, in draft II the media had received expert approval and was ready to be tested in the field with the results of the language validation test showing a score of 3.66 for the effectiveness of the sentences used, 3.75 for the communicative language used and 4.00 for the interactive language used. With the average score of the language used in the media as a whole is 3.75

\section{$>$ Description and Analysis of Media Practicality}

The practicality of the media was obtained from the results of teacher and student questionnaires. The teacher response questionnaire on the level of media practicality was obtained after the trial process in fifth grade at elementary school Genilangit 02 showed the media practicality score showed a score of 3.89 without suggestions for improvement from the respondent. The student response questionnaire showed an average score of 4.00 without suggestions for improvement from the respondent.
The implementation of the Learning Process in Improving Student Listening Skills illustrates the increase in student listening skills which is shown by the level of enthusiasm of students towards the material presented through the iSpring 8 media assisted by power points, indicated by the number of students who respond to material from the media presented in the form of simulations. In addition, students can complete tasks that are contained in the media well, followed by several students conveying their work based on the tasks that are listened to from the media to the front of the class the percentage of student activity is $100 \%$ for affective and $100 \%$ for psychomotor, without any obstacles during the test process. try media.

\section{$>$ Description and Analysis of Media Effectiveness}

The effectiveness of the media is obtained from the results of the questionnaire and test results after the media testing process. The results of the questionnaire for the response of the fifth grade homeroom teacher at elementary school Genilangit 02 were nine questionnaire items, the check list showed a score of 3.89 without suggestions for improvement from the respondent. Student response questionnaire with nine questions with an average score of 4.00 without suggestions for improvement from the respondent. The test questions for the effectiveness of the iSpring 8 media assisted with power points against fifth grade students, which amounted to eight students, showed an increase in student learning outcomes listening skills at the pre-test stage, students showed an average value of 6 , 00 there were 4 students who did not complete with a percentage of $50 \%$ completeness while the value of the learning outcomes of listening skills after the iSpring 8 learning media trial assisted with power point at the post test stage showed an average value of 8.37. The lower limit value of student completeness for Indonesian is 7.00, there are 2 students who do not complete with a completeness percentage of $80 \%$. Student activities during the learning process using iSpring 8 media assisted with power point showed the affective students with an average of 3.67 with $100 \%$ completeness and an average of 3.34 psychomotor with $100 \%$ completeness.

\section{DISCUSSION}

\section{> ISpring 8 Media Development Process Assisted by Power Point}

The description of the iSpring 8 learning media development process assisted by power point shows the feasibility level of the development process of the series of processes carried out which includes initial to final interviews with the homeroom teacher of fifth grade at elementary school Genilngit 02 and the results of the development process validator assessment carried out based on the draft media design showing the iSpring 8 media aided power point is very feasible in the development process with an average score of 3.90 from a maximum score of 4.0 with this score the media can be declared very good to be tested. This condition is in line with the results of Kurniasih's (2016) research, namely the results of the development of iSpring multimedia-based teaching aids 
which was developed using the R \& D by the researcher falls into the good category with the results of material experts from teacher 1 of $88.5 \%$, teacher 2 of 87.6 , and media experts of $88.3 \%$. Power point assisted iSpring 8 media development can be developed with a Four-D development model with very feasible criteria.

\section{$>$ The validity of ISpring 8 Media assisted with Power Point}

The validity of the iSpring 8 media assisted with power point based on validation data, the validity of the media was 3.76 , the validity of the material was 3.71 , the validity of the language was 3.75 with the maximum score for each aspect was 4.0 making the iSpring 8 media assisted by power point with very good criteria. In line with research conducted by Himamah (2017) interactive multimedia based on iSpring Suite 8 on valid additive materials based on the assessment of media experts and material experts with an average score percentage of $85.19 \%$ with very feasible criteria. Development of iSpring 8 learning media with power assistance point using the Four-D model based on the results of expert judgment and its relevance to theory, iSpring media which is declared high quality and has high validity to improve listening skills of fifth grade elementary school students.

\section{$>$ ISpring 8 Media Practicality Aided Power Point}

The data from the questionnaire results of teachers and students showed that the iSpring 8 learning media assisted with power point was very good with the acquisition of a teacher response score of 3.89 and the overall average score of students was 4.0 out of a maximum score of 4.0, the results of the questionnaire showed the level of media practicality. iSpring 8 assisted with power point based on student response can be said to be very good without the need for improvement. In line with Himamah's research (2017) that learning using interactive multimedia makes learning fun and interesting with a percentage of $97.22 \%$. With the practical value of interactive multimedia based on iSpring Suite 8 in the sub-material of practical additives based on the implementation of learning with an average score percentage of $93.9 \%$ with very feasible criteria and a positive student response of $98,33 \%$ with very feasible criteria. Based on the results of the test results for the implementation of the RPP of the iSpring 8 media assisted by the power ponint obtained from the observation data of the learning process, it shows that the level of implementation of the lesson plans is very good with the average student activity in the domain of student attitudes is $100 \%$ and $100 \%$ in the student psychomotor domain. In line with research conducted by Himamah (2017) on learning using interactive multimedia based on iSpring Suite 8 on additive sub-material in class VIII-A of SMPN 1 Puri, it has been carried out very well with an average percentage of RPP implementation of $93.9 \%$.

\section{DEfectiveness of Power Point Assisted ISpring 8 Media}

The data obtained from the teacher's response questionnaire score of 3.83 and the student response questionnaire 4.0 from a maximum score of 4.0. The results of the questionnaire showed the effectiveness of the iSpring
8 media assisted with power point based on teacher and student responses very well without the need for improvement. Student test results data obtained from pretest questions to measure students' listening skills without using media with an average score of 6.0 student test results with a total percentage of students completing the test is $50 \%$. The post-test result data given after the iSpring 8 learning media trial using power point showed the average post-test results of students with a value of 8.38 with a percentage of $80 \%$ completeness, the average increase in student scores was $2.37(23.7 \%)$, the level of student completeness also increased by $30 \%$. In line with the opinion of Sudjana, et al. (2009) the benefits of learning media are that students do more learning activities because they do not only listen to the teacher's explanation, but also do other activities such as observing, doing, and presenting the results obtained from the discussion. In line with the research conducted by Wijayanto (2017) regarding the improvement of learning outcomes with the ispring suit, it shows results $(94.7 \%)$ with a comparison of learning outcomes between the experimental group and the control group 77.9 and 73.4. Kurniasih's (2016) study of iSpring learning media has an influence on students' learning outcomes in logic tests. It can be seen from the experimental class, the logic test score is higher and the post test result is higher than the control class. The average post-test result for the control class was 72.258 , while the average post-test result for the experimental class was 77.419 .

The results of the assessment of student activity in the attitude domain percentage of $100 \%$ and the percentage of student activity in the psychomotor domain of $100 \%$. The iSpring 8 media is assisted by power point with quality criteria in terms of effectiveness in improving the listening ability of fifth grade elementary school students and can be used as a basis for consideration in media dissemination.

\section{CONCLUSION}

The process of developing iSpring 8 learning media assisted with power point developed using the Four-D model has been carried out based on systematic stages and adjustments to the media development design in terms of its development format and has gone through the validation stage by media experts with the results showing the feasibility of the process of developing assisted iSpring 8 learning media a power point and feasible to be tested to determine the feasibility level in improving the listening skills of fifth grade elementary school students for further production and dissemination.

The quality of the media which includes validity, practicality, and effectiveness has gone through a series of tests by experts and field trials which show the validity of the iSpring 8 media assisted by power point after conducting media validation tests on media experts, material experts and linguists showing the results of media development iSpring 8 has a high quality of validity in terms of media and material content which improves the listening skills of fifth grade elementary school students so 
that it is ready to be tested and disseminated,the practicality of the power point assisted iSpring 8 media showed excellent results after the media trial process was carried out at elementary school Genilangit 02 , thus the iSpring 8 learning media assisted with quality power points in terms of practicality to be applied in elementary schools in an effort to improve the listening skills of fifth grade students obtained From the results of questionnaires to students and homeroom teachers of fifth grade at elementary school Genilangit 02, the effectiveness of the iSpring 8 learning media assisted by power point after conducting media trials and data collection for the respondents which included fifth grade students and homeroom teachers of fifth at elementary school Genilangit 02 , it can be concluded that the iSpring media 8 assisted with quality power points in terms of effectiveness in improving listening skills for fifth grade elementary school students as shown by the results of student questionnaires, teacher questionnaires,and student test results.

The developed iSpring 8 learning media assisted with power point has the advantage of being able to be transmitted online and offline from the teacher to students by utilizing Siakad, Sepaka, and communication networks. This media can also be operated independently by students or as a learning medium in the classroom by the teacher. The weakness of this media is that it requires a computer device or device to operate. In addition, for the broad transmission of power point-assisted iSpring 8 media requires an internet network and Siakad or Sepadak so that it can be used by many users.

\section{REFERENCES}

[1]. Abidin, Yunus. (2015). Pembelajaran Multiliterasi. Bandung: Refika Aditama.

[2]. Arsyad, Ashar. (2014). Media Pembelajaran. Depok: Rajagrafindo Persada.

[3]. Djuanda, Dadan. (2008). Pembelajaran Keterampilan Berbahasa Indonesia di Sekolah Dasar. Bandung: Pustaka Latifah.

[4]. Himamah, Faiqotul, Martini. (2017).Pengembangan Multimedia Interaktif Menggunakan Ispring Suite 8 pada Submateri Zat Aditif untuk Meningkatkan Hasil Belajar Siswa SMP Kelas VIII. E-Journal Unesa. Vol. 05 (02), pp. $73-82$.

[5]. Kemp, Jerrold E. (1994). Designing Effective Instruction. New York: Macmillan College.

[6]. Kursinah, Sari Yuni. (2016). Pengembangan teaching aids ispring presentation untuk mengembangkan logika berpikir dan meningkatkan hasil belajar siswa pada materi teorema Pythagoras di smp N 39 Semarang.

[7]. Munadi, Yudi. (2013). Media Pembelajaran (sebuah Pendekatan Baru). Jakarta: Referensi Pers Grup.

[8]. Nurjaman, J. A. (2014). Software Pendidikan iSpring Presenter. http://jajangcahayajaman.blogspot.co.id/2014/07/software-pendidikan- ispringpresenter.html.
[9]. Nurwijayanti, Ani. (2019). Combining Google Sketchup And Ispring Suite 8: A Breakthrough To Develop Geometry Learning Media. Journal on Mathematics Education, Vol. 10 (1), pp. 116103.

[10]. Oya, Rini Ntowe, Asri Budiningsih. (2014). Increasing the Motivation and Learning Achievement of Indonesian Using Creative and Productive Learning Model. Jurnal Prima Edukasia, Vol. 2 (1)

[11]. Sudjana, Nana. (2009). Penimedia Pembelajaran. Bandung: sinar baru algesindo

[12]. Sugiyono. (2012). Metode Penelitian Kuantitatif, Kualitatif, dan R\&D. Bandung: Alfabeta.

[13]. Syukron Fatah. (2008). Teknologi Pendidikan. Semarang: RaSAIL Media Grup.

[14]. Tarigan, H. G. (2008). Menyimak: sebagai suatu Keterampilan Berbahasa. Bandung:Angkasa.

[15]. Wijayanto, dkk. (2017). Ncreasing Student's Motivation and Geography Learning Outcome Using Active Debate Method Assisted by Ispring Suite. State University Of Malang. Geography Education, Postgraduate Program. Indonesia ${ }^{2}$ state University Of Malang, Indonesia Int. J. Soc. Sc. Manage. Vol. 4, Issue-4: 240-247 Doi: 10.3126/Ijssm.V4i4.18336. 